\title{
\#FeministAntibodies: Asian American Media in the Time of Coronavirus
}

\author{
Rachel Kuo' (D), Amy Zhang², Vivian Shaw³, \\ and Cynthia Wang ${ }^{4}$
}

\begin{abstract}
This article examines the tensions, communal processes, and narrative frameworks behind producing collective racial politics across differences. As digital media objects, the Asian American Feminist Collective's zine Asian American Feminist Antibodies: Care in the Time of Coronavirus and corresponding \#FeministAntibodies Tweetchat responds directly to and anticipates a social media and information environment that has racialized COVID-19 in the language of Asian-ness. Writing from an autoethnographical perspective and using collaborative methods of qualitative discourse analysis as feminist scholars, mediamakers, and interlocuters, this article looks toward the technological infrastructures, social economies, and material forms of Asian American digital media-making in the midst of the COVID-I 9 pandemic.
\end{abstract}

\section{Keywords}

feminist media, Twitter, social media, Asian American, activism

"For me, this space of radical openness is a margin - a profound edge. Locating oneself there is difficult yet necessary. It is not a 'safe' place. One is always at risk. One needs a community of resistance.” (hooks, 1989, p. 206)

The mediatization of "Asian-ness" as contagion has been a large part of the information environment surrounding the 2020 COVID-19 pandemic. Mainstream media outlets have used generic images of Chinatowns and East Asian people in masks without context; racist comments and false information about avoiding Asian businesses have spread on social media platforms; and continuing communication from the Trump administration racializes the virus as the "Chinese virus." Simultaneously, in the United States, media coverage of coronavirus-related racism toward Asians and Asian Americans have reinforced perceptions of Asian America as both monolithic and East Asian/Chinese-centric. In anticipating and responding directly to a racially hostile media and information environment, digital media created by Asian American organizers, community groups, and artists in the midst of the COVID-19 crisis have grappled with tensions between forging collective politics while also pushing against presumptions of racial homogeneity. Backlash from some Asian Americans against shirts proclaiming "I am not Chinese" and former Democratic presidential hopeful Andrew Yang's call for Asians to be "more American" demonstrate the contentious politics of Asian American identity (Kuo, 2018).
In the early stages of the pandemic, a multitude of digital outputs began making up a rich media ecosystem, demonstrating the depth and breadth of Asian American knowledges, histories, and experiences in making meaning and living through the COVID-19 pandemic. Alice Wong, Director of the Disability Visibility Project, curated a sample of 1,299 tweets (Wong, 2020) about coronavirus from the perspectives of homebound, chronically ill, and immunosuppressed people. Writer Leah Lakshmi Piepzna-Samarasinha (2020) published emergency preparation tips from her survival experiences of being poor and disabled. Artist Monyee Chau (2020a) created a comic on Yellow Peril and community resilience to share the history of Seattle's International District to generate donations for the Wing Luke Museum of the Asian Pacific American Experience. These resources and more draw on community-based knowledge to distribute

\footnotetext{
'The University of North Carolina at Chapel Hill, USA

${ }^{2}$ The University of Texas at Austin, USA

${ }^{3}$ Harvard University, USA

${ }^{4}$ California State University, Los Angeles, USA

Corresponding Author:

Rachel Kuo, Center for Information, Technology, and Public Life, The University of North Carolina at Chapel Hill, 100 Manning Hall, CB 3360 , Chapel Hill, NC 25799, USA.

Email: rskuo@email.unc.edu; @rachelkuo
} 
information and identify historical and political frameworks for understanding state-based and racial violence.

The New York City-based Asian American Feminist Collective's (AAFC) digital zine Asian American Feminist Antibodies: Care in the Time of Coronavirus curated different media artifacts created prior to and during the crisis as an archive of Asian American political mobilization. In early March 2020, AAFC, along with community partner Bluestockings Bookstore, Cafe, and Activist Center, initiated a call to collect firsthand accounts of experiences with racism connected to COVID-19, resulting in 36 unique stories of varying lengths describing the feelings and experiences of public harassment and targeting in grocery stores, schools, public transport, and other sites of daily encounter. As an example of media-based organizing, which is a collaborative process using media, art, and technology to envision solutions to interconnected systemic issues (Allied Media Projects, 2020), the zine connected these firsthand accounts with analyses from community organizers and activists. Furthermore, the zine emphasizes that despite this moment of precarity, there is both "deep collective knowledge" and "radical possibilities" toward realizing "dreams, visions, and desires for an alternative world" and building "interdependent communities of resistance" (Bhaman et al., 2020, p. 3).

Later, on 10 April 2020, AAFC and Bluestockings hosted a community Tweetchat with 12 invited participants representing different organizations and campaigns under the hashtag \#FeministAntibodies. The Tweetchat was organized around seven different questions, offering the invited participants a space to discuss Asian American experiences of the pandemic through the frameworks of community and care, reflect on historical parallels, and share resources. This coordinated effort to bring different actors into a shared space and time also afforded the opportunity for other people to join the conversation using the \#FeministAntibodies hashtag. These media practices function as rapid response strategies with a vision of longer term movement building. Drawing on different perspectives across different community groups and movements, the zine and corresponding Tweetchat aimed to foster political alignments across differential experiences of crisis-thus, these digital materials help facilitate what bell hooks (1990) calls a "homeplace," a communal site of resistance.

This article looks to the technological infrastructures, social economies, and material forms of Asian American digital media-making in the midst of the COVID-19 pandemic. Focusing on AAFC's zine Care in the Time of Coronavirus and the corresponding hosted Tweetchat \#FeministAntibodies, this article highlights the tensions, communal processes, and narrative frameworks behind producing collective racial politics across differences. We write from an autoethnographical perspective as the zine's creators and Tweetchat's organizers, use collaborative qualitative discursive methods as Asian American feminist scholars, media practitioners, and interlocuters, and bring critical technocultural discourse analysis (CTDA) to ground our study of digital texts (Brock, 2016). Through CTDA, we demonstrate how digital discursive practices constitute and evolve identity-based political positionality. In examining both the media-making process and content within the zine and Tweetchat, we found three emergent themes in how different actors understand, define, and mobilize Asian American collective politics: (1) as intersectional and diverse, (2) as constituted interdependently, and (3) as a site for imagining political possibility through different histories. This study extends scholarship on the cultural and racial politics of media, including Lisa Lowe's (1998) discussion of cultural production and subjectivity and Lori Kido Lopez's (2016) discussion of Asian American media activism as cultural citizenship; the uses of social media to develop counter narratives and build networks of dissent (Jackson et al., 2020), and contributes to discussions of how race "works" online (Nakamura \& Chow-White, 2013).

In the ways that COVID-19 has been described through the language and narratives of contagion, it is apt that the collective political uses and circulation of hashtags by Asian Americans on Twitter and other social media platforms create what Sanjay Sharma (2013) describes as the "contagious effects of networked relations" (p. 48) in producing politics. This article begins with an overview of Asian American cultural politics and the mediation of race in online platforms, followed by a discussion of political formation and temporality in the time of crisis to contextualize Asian American digital organizing in the midst of COVID-19. We then discuss our methodological approaches in the creation and analysis of digital text. In our findings, we argue that processes of digital organizing offer a means to articulate Asian America as a political formation through navigating uneven social differences.

\section{Asian American Cultural Politics and Digital Production}

Tweeting as a political act, or what feminist scholar bell hooks (1989) calls "the margins", showcases digital mediamaking as sites of "radical possibility, a space of resistance" (p. 149). Digital media outputs, such as zines, short illustrated comics posted to Instagram, and tweets constitute "minor objects ... marginal forms, persons and worlds mobilized in narrative (including archival) constructions to designate moments of crisis" (Nguyen, 2015, p. 12). Similarly, these objects extend Lisa Lowe's (1996) discussion of Asian womens' worker testimonials as "crucial media that connect subjects to social relations" (p. 33). In other words, these digital records can organize collective politics. Asian American digital media production extends from print technologies and movement media histories of grassroots publications of newsletters, circulars, pamphlets, and zines (Kuo, 2017). For example, during 1960s and 1970s, leftist Asian American organizations produced and circulated their own 
movement media, such as Gidra and Basement Workshop's Bridge Magazine (Ishizuka, 2016). Deepa Iyer (2017) describes grassroots media as utilizing the stories from the lived experiences and leadership of those facing multiple levels of injustice and inequities to equip and mobilize people around campaigns. Part of an alternative, progressive media ecosystem, independently published media circulated movement discourse to develop shared political imagination, build political vision, challenge dominant paradigms, and construct solidarities.

Asian American feminism as politics is also constructed through ongoing technological discourse. For example, since 2018, AAFC has created digital and print zines and facilitated online discussions to interrogate and reflect upon feminism as an ever-evolving political practice and approach. Such acts of media-making inherit both longer and more recent histories of feminist media artifacts, from the Third World Women's Alliance's Triple Jeopardy newsletters in the 1970s to hashtags such as \#SolidarityisforWhiteWomen and \#NotYourAsianSidekick in 2013 (Kuo, 2017). Scholarship of digital activism has shown us how marginalized groups excluded from mainstream media spaces have used digital technologies for counter narratives, "talking back" (Jackson et al., 2020; Steele, 2017), political debate, and building movement networks. However, Black feminist scholars have also challenged neoliberal narratives of digital technologies/social media as sources of liberation and empowerment (Noble, 2016). Different users are valued differently by corporate platforms based on social differencefor example, racial ideologies embedded within algorithms play a role in facilitating disparate systems of value in how information is accessed and circulated online (McIlwain, 2017). In the adaptation of Asian American cultural politics in digital spaces, Victor Bascara and Lisa Nakamura (2014) point us toward the significance of how different digital platforms transform cultural and political formations. They argue that beyond a narrow focus on representation through text and image, engaging how platforms intersect and shape racial processes and relations enable us to see the capacities, exclusions, and surveillance of racial bodies in digital space.

In beginning to write this article in early May 2020, because of city and state social distancing and shelter-in mandates due to COVID-19, many of the social and political spaces we collectively inhabit are virtual. Yet, as much as digital media platforms have enabled Asian American media production, systems of oppression including vitriolic hate speech and harassment continue to propagate in online spaces. COVID-19 has exposed rampant existing inequalities of people's access to safety, including digital safety. The idea of "free speech" becomes complicated when corporate platforms like Twitter become weaponized for harassment and abuse, disproportionately against women and communities of color. The same technological affordances for political mobilization and expression can also be used by White supremacists and hate groups, with "Zoom bombings" entering the digital space as a racist tool of abuse. Digital organizing tactics, such as Tweetchats and Tweetstorms, or multitudes of Tweets posted all at once using a hashtag identifier, have extended and corresponded with analog forms of movement strategy through the act of reclaiming space in an exhausting, relentlessly racist digital media environment.

\section{Organizing in the Time of Crisis}

Feminist organizing during a pandemic is fraught with social and political imperatives that preceded COVID-19. Frames of crisis that position this moment as new and temporary camouflage systems of power and exploitation that are operating as designed. Instead, we understand the crisis as a consolidating moment of racialcapitalism.Asactivistsin\#FeministAntibodies and Care in the Time of Coronavirus have suggested, the US President Trump's stoking of anti-Asian racism through disinformation and Sinophobic monikers, such as "Kung Flu" and "Chinese virus," operate alongside the shock doctrine of eroding environmental protections through COVID-19 recovery legislation. For as long as they remain unresolved, crises portend a multiplicity of potential outcomes. These uncertainties influence activism and organizing, as well as the documentation of these efforts (Gilmore, 2007).

The neoliberal logics that enable states to avoid responsibilities during disasters such as Hurricane Katrina, Hurricane Maria, and now COVID-19 ironically underscore the necessity of mutual aid and other community-based political alternatives. When states dismiss their obligation to protect and care for vulnerable groups as "voluntary," they create a vacuum for activists to fill (Nickel \& Eikenberry, 2007). For example, the Japanese government's misinformation about the Fukushima nuclear disaster in 2011, combined with its retrenchment of civil liberties and endorsement of ultraright militarism in the years following, catalyzed a durable network of activists (Shaw, 2020). As these activists connected the rise of anti-Korean hate speech in 2013 to the state's failure to protect multiple groups of vulnerable people, they began to envision antiracism as central to their task of rebuilding their communities (Shaw, 2017). Moreover, they prioritized their own social connections above recognition from the state as a source of legitimacy. In this example, activists re-centered political membership around "obligation, mutual protection, and struggle - which not only includes the disaster but also refers to the temporality of protests themselves - as a collective experience" (Shaw, 2017, p. 73). In moments when states use disasters to levy additional harms on already injured communities, activists sometimes create new political coalitions (Tang, 2011).

\section{Methodologies: On Process, Collaboration, and Making Data}

Focusing on the zine Care in the Time of Coronavirus and \#FeministAntibodies Tweetchat, this article brings together 
autoethnographic reflections on media-based organizing with qualitative discourse analysis of text. Together, these methods intervene upon "big data" approaches to studies of digital media through "deeper" data by offering an intimate way to study, understand, and contextualize processes of media production (Brock, 2015). Furthermore, these methods also unveil a process of data-making - how datasets are co-produced through research interventions (Vis, 2013). Our process-oriented approach also draws upon Dorothy Kim and Eunsong Kim's (2014) \#TwitterEthicsManifesto, which rejects object-oriented and birds-eye approaches to digital research, and instead foregrounds circular and participatory systems. In using an autoethnographic approach that draws on personal experience and position (Bailey, 2015; Korn, 2017), author Rachel Kuo writes from the reflexive position of facilitating the zine's creation and organizing the Tweetchat as one of the co-leaders of the Asian American Feminist Collective in collaboration with author Vivian Shaw in the zine's editorial process.

We invited authors Amy Zhang and Cynthia Wang as feminist interlocutors with these digital texts. Together, we coded the tweets through a qualitative inductive process, using observations of the Tweetchat's process and content to find emergent themes about Asian American collective politics in these digital narratives. We see the process of collaboration as feminist methodology_working and thinking together to think as integral to intellectual and political inquiry. In collaborating remotely, we developed an infrastructure of digital documents, messaging channels, and scheduling meetings that enabled collective discussion of the findings. As scholars across the fields of communication, media studies, and sociology, beyond the content of the digital materials themselves, we also discussed our shared (and also divergent) theories of race and methodological approaches to learn cross-disciplinarily from each other.

To incorporate critical race and feminist theory and center the "epistemological standpoint" of underserved users, we bring CTDA to our qualitative study of digital text (Brock, 2016). As a technique, CTDA assesses user discourse alongside the technological and material specificities of media platforms, connecting together form, function, and meaning. For example, CTDA considers how differences between mobile and desktop uses of Twitter - the holding of a handheld device with fingers brushing the screen versus typing at a laptop-change how a user may participate in a digital space, including different forms of political participation. As a method, CTDA seeks to reveal the political meanings embedded within technologies through examining their situated uses. Taking Asian American feminism as a grounding point - specifically, how it becomes articulated, defined, and operationalized within technocultural spaces - we use CTDA to inform an understanding of the making of collective politics by different actors across discursive platforms during a particular point in time. In this way, CTDA connects with our autoethnographic and collaborative approaches to critically consider how our own position and practices as Asian American feminists on Twitter and other digital platforms also inform our interactions with and understandings of our research materials.

As a field site for examining Asian American politics, hashtags "performatively frame" racial meaning as well as archiving and indexing racial discourses in an "intertextual chain" (Bonilla \& Rosa, 2015). The \#FeministAntibodies Tweetchat generated over 300 original tweets (not including social engagement, such as retweets, likes, or shares). Kuo created a public archive of the chat using Wakelet, a visual content platform for organizing and curating online information. Wakelet functions as a substitute to Storify, a narrative timeline platform that was shut down in May 2018, leaving people scrambling to download their stories or risk them disappearing forever. The \#FeministAntibodies Wakelet archive includes 315 different posts organized by the seven questions posed by AAFC during the chat (Asian American Feminist Collective, 2020a). Using a platform external to Twitter allows for both a re-evaluation and temporal re-organization of information, since the search functions on Twitter only easily afford reading the most recent posts first and also prioritizing posts with the highest engagement.

In late April, the four authors coded all of the tweets from Wakelet, organized by the Tweetchat's seven questions to identify emergent themes. The questions, edited for length, include the following: (1) How are Asian American communities experiencing the pandemic? (2) What kinds of community resources are missing in this moment for Asian American communities and individuals? (3) What practices of care are fueling you and providing you solace in this difficult moment? (4) What does revolutionary love and care mean for you? (5) What parallels in history are we seeing? (6) What mutual aid funds should we be supporting? and (7) What kind of world would you like to build for the future? These questions invited participants to both make sense of the pandemic through historical contexts as well as circulate and construct shared political visions.

After the coding process, the authors discussed themes they observed in their reading and interpretation, arriving at three emergent themes that revealed how political actors within the Tweetchat were understanding and defining "Asian American collective politics": (1) assertions that Asian American identities are intersectional and diverse, (2) narratives of interdependency within Asian American communities as well as solidarity with other marginalized communities, and (3) using historical and contemporary critiques of systems of violence to imagine future possibilities. In the findings and analysis that follow, we first share details from the coordination and curation process of both the zine and Tweetchat. Rather than solely focus on movement outputs, such as the tweets themselves, we emphasize the immaterial and feminized labor in processes of movement building across different digital architectures. We then turn to a discussion of the emergent themes from the 
\#FeministAntibodies Tweetchat and implications of these themes in Asian American cultural production and politics.

\section{Care in the Time of Coronavirus: Making Asian American Feminist Media}

Before its final form as a digital PDF, the AAFC's zine Asian American Feminist Antibodies: Care in the Time of Coronavirus existed over messy notes, emails, and Google documents. Media coverage and scholarship of social movements often fail to acknowledge the mundane and quotidian processes of media-making and the feminized and devalued administrative and technical labor of creating digital media outputs. Matilda Sabal, a volunteer for Bluestockings Bookstore, originally reached out to AAFC to volunteer their time, resources, and labor after witnessing multiple incidents of anti-Asian racism in their local community. After several email exchanges, plans were drafted for an open submissions call. The zine's editorial team drew primarily on their existing networks, reaching out to friends they had previously organized and worked alongside; later, they also privately messaged poets, artists, and writers. Most contributors were quick to reply, generously lending their work and perspectives to the zine and expressing ways this project felt meaningful to them. One user on Twitter regularly messaged AAFC directly to share posts from their feed where Asian Americans were discussing instances of racism. These acts of reaching out to one another and bringing people in function as gestures for connection. These acts of extending the reach of the self into space forge meaningful political coalitions - "bring[ing] into the possibility of a "we" (Rodriguez, 2014, p. 2). The ways we touch, reach, make space, and connect reveal how we relate to those with whom we build community.

There are many limits to and critiques of using corporate technologies such as Google Drive to develop communitybased communications infrastructures, such as data surveillance and the overvaluation of productivity. However, we might also consider how feminist uses of these technologies can reappropriate capitalist logics embedded within these technologies. This might include using the comments feature in Google Docs to offer expressions of gratitude, ask if someone needs support, or think and learn new histories and languages alongside other people. The zine itself functioned as a means to bring people into space together through the figurative and literal space of a digital object. The proximities forged through the use of space - the alignment of text and images reflect and express political alignments and orientations.

To generate further conversation from the zine and create additional space for dialogue, AAFC and Bluestockings hosted an hour-long Tweetchat on community care on 10 April 2020 using the hashtag \#FeministAntibodies (Asian American Feminist Collective, 2020b). Different leaders within AAFC took on different tasks: generating questions, designing graphics, and pre-writing tweets to post during the event. AAFC also reached out to community partners. In addition to individual contributors, invited participants represented leftist and anti-authoritarian organizations, groups, and campaigns such as Equality Labs, Nodutdol, Red Canary Song, and Free Them All for Public Health. Partners received questions in advance to allow for preparation in addition to a timeline for when questions for the chat would be posted; this is reflected in the flow of the Tweetchat itself, as the majority of the content comes from invited partners. The shared labor of preparation affords a dynamism within the conversation itself as an illusion of live-ness that invites other interlocutors to participate.

During the Tweetchat, Kuo posted from AAFC's and her individual user account, using Twitter on different browsers to participate as both the organization and herself. She used a Google doc of pre-written tweets and also participated in a live video chat with other AAFC leaders. Another leader of the collective spent the entire hour using Tweetdeck, a browser extension, to retweet and engage posts from other users participating in the conversation. The uses of different platforms adjusted for limitations on interfaces. Emphasizing the collective work behind producing the Tweetchat, such as assembling together notes and threading together information, reveals laboring figures behind the machine (Green, 2011; Nakamura, 2011).

Organizing within the context of the COVID-19 pandemic demonstrates the milieu of ways we bring movement work home. Prior to the pandemic, AAFC's monthly Sunday meetings rotated between different collective leaders' homes. bell hooks (1989) describes a homeplace as one about building a safe space for healing, affirmation, and growth within racist systems. Or, as Barbara Smith (1989) describes of the Kitchen Table Press, the kitchen is the center of a home for work and communication and the kitchen table represents a grassroots operation. The table can also be the site of a feminist point, a surface for political work. The table and the home have often been the site of "networking" space to foster belonging - collectively, it is a place for relationship building and gathering together. The next section turns toward the digital discourses circulating within the \#FeministAntibodies chat to consider how perspectives, orientations, and inheritances of political and intellectual worlds and histories mobilize a particular orientation to Asian American collective politics.

\section{\#FeministAntibodies Tweetchat: Collective Orientations}

This section discusses the three emergent themes from the coordinated \#FeministAntibodies Tweetchat, interpreting how different political actors understand and define "Asian America" as a political formation that is (1) intersectional (or "not a monolith"), (2) interdependent, and (3) with interconnected histories. The Tweetchat offers a specific discursive articulation of Asian American collective politics within a 
technocultural space as a way to intervene upon and remediate the racialization of Asian-ness during the COVID-19 pandemic.

Together, the three themes challenge neoliberal norms in both our technological and political culture, which fragment identity-based differences into discrete, individual categories by instead emphasizing difference as the foundation toward building collective politics. The neoliberalization of identity politics has reduced identity onto the level of the individual, rather than membership in collective struggles against oppressive systems and structures. Capitalism has been a medium in which community enacts itself (Joseph, 2002), and digital platforms function as a site to both produce and consume identity. For example, Wendy Hui Kyong Chun (2016) discusses how digital networks generate a neoliberal "you," rather than a collective "we" through a market of information. However, feminist and queer uses of platforms can reflexively use neoliberal logics embedded into platforms to circulate alternative imaginings. Rather than address anti-Asian racism during the COVID-19 pandemic at the level of individual injury, we interpret the Tweetchat's themes as challenging dominant discourses around recognition based on individual difference to instead re-imagine difference as a building block for mass opposition against racism and capitalism. In this vein, the Tweetchat also demonstrates Asian American feminism as entangled with discursive media technologies.

\section{"Not a Monolith"-A Call for Intersectionality}

AsAm communities are not experiencing this as a monolith. Asians who are East/SE Asian, incarcerated, Muslim, working class, undocumented, queer\&trans, survivors, houseless are facing racialized violence \& need intra-community support \& solidarity. (Sharma, 2020a, April 10)

Participants in the Tweetchat identified a necessity in extending and expanding the reach of Asian American collective formation. They stressed the need to push against the construction of Asian America as a "monolith," a specific intervention given the disproportionate focus on East Asian populations by both mainstream news media coverage of COVID-19 as well as Asian American media responses to this coverage. They also highlighted the importance of intersectionality as a framework for building collective politics given differential experiences of disaster under multiple systems of power. While some early media accounts of the pandemic expressed hope for shared unity, the crisis exposed how combined factors including race, ethnicity, religion, class, gender, and other defining factors (Collins, 2015) differentially shape people's experiences. For example, people of color are infected and dying at faster rates during the pandemic, have less access to health care resources, and experience greater job instability (Devakumar et al., 2020). Participants emphasized the different ways particular groups were facing racialized violence; for example, Equality Labs (2020), a Dalit-led South Asian feminist organization, observed, "Bangladeshi communities have to close their shops and have no access to aid" as well as a "huge uptick in hate-speech connecting Muslim people to COVID-19”(@Equality Labs, April 10).

Participants cited differential access to resources as well as unequally distributed exposure to state violence, testifying to how the social and economic ramifications of COVID-19 impacted Asian populations in different ways. The potential for harassment, coupled with increased stress regarding potential economic loss, escalates during times of crisis (Peek, 2011), as testified to by Tweetchat participants who mentioned immigrant-owned stores, such as groceries, nail salons, and restaurants, in their communities closing. Red Canary Song (2020), a grassroots collective organizing Asian sex workers, highlighted how informal sector workers lack an unemployment safety net: “ . . . Street vendors, day laborers, domestic workers \& sex workers put themselves at risk. While there are few funds for gig workers, criminalized \& undocumented workers esp. need more support \& solidarity" (@RedCanarySong, April 10).

Long-standing stereotypes and biases in the mainstream media landscape, such as the model minority myth which casts Asians as upwardly mobile and economically successful, have tended to depict Asian Americans as homogeneous. However, Asian American activists have long worked to counter these perceptions - as a collective identity, Asian America was formed out of political movements during the Civil Rights era, in solidarity with Black liberation movements. In emphasizing intersectionality and challenging Asian America as a monolith, participants also called for building intra-community and cross-community solidarities. During the Tweetchat, rather than approach the lack of resources from tenets of individualism premised upon scarcity and intra-group competition, participants observed that pan-Asian collective action would benefit all Asian Americans during this time. For example, Nodutdol (2020), a grassroots Korean organization against war and militarism, shared that the pandemic "cuts across race and class . .. As anti-Asian racism is on the rise again, we also need to acknowledge how Black and Brown communities are disproportionately being affected [-] to build cross-community solidarity" (@Nodutdol,2020,10 April). Rather than take individual identity and recognition as a starting point, intersectional methods countering oppressive structures produce community formations in spite of (or because of) difference (Nash, 2019).

Participants identified racial tensions between communities of color, including how anti-Blackness within Asian American communities remains conspicuous during a time when Asian Americans are targets of racial hostility- the perspectives of Black Asians are notably largely missing from this dialogue. Participants stressed the need to "show up" for other impacted communities, highlighting the need for solidarity work between Asian Americans and medically 
vulnerable populations disproportionately impacted by COVID-19. Under externalized stress and grief during the coronavirus pandemic, this moment has seen tensions between narrow bids for inclusion and access to resources as well as calls to build across differences. In foregrounding difference, participants within the \#FeministAntibodies Tweetchat outlined a vision for collective formation that emphasized community interdependence.

\section{"Community is Growing"-Collectivity and Interdependence}

It means breaking social norms instilled in us, embracing intimacy, sharing vulnerable spaces. It means re-centering collectivism and making sure everyone has a space in the world we want to create together. (Chau, 2020b, April 10)

The Tweetchat highlighted interdependence between individuals, families, and communities despite government neglect. Participants emphasized the importance of community-based mutual aid networks in responding to governmental indifference and emphasized models of caring for each other by sharing resources and support. For example, Shahana Hanif (2020), a language justice advocate, highlighted the importance of community translation and interpretation to not only expand immigrant access to resources but also "create a culture of shifting power, expand democratic participation, and [center] the wellness and survival of the most disenfranchised communities" (@) ShahanaFromBK, 10 April).

In addition, in a moment of social and economic crisis, participants countered neoliberal individualism, which values individual responsibility, by presenting a feminist framework of interdependency and collective accountability to one another. Many acknowledged the need to carve out a space to heal, while asserting that productivity did not equate to worth - a direct critique of and movement against capitalist notions of labor which alienates workers from their own humanity in service of economic profit (hooks, 1990). Disabled artist and activist and Bluestockings volunteer Matilda Sabal (2020) highlighted practices of interdependency to build intimacy across distance and isolation, drawing on the long legacy of disability justice movements: "calling friends \& comrades, coworking over Zoom, building space for rest and joy ... the revolutionary work can be done anywhere, even your bed"(@fierce_invalids,10 April).The emphasis on creating space for rest and joy through the uses of different technologies decenters notions of individual productivity. Such a pivot counters social relations structured by capitalism. In this vein, participants also emphasize care work and reproductive labor in their digital practices as a means of community support - the work of physically, materially, and emotionally preparing people to continue revolutionizing (Federici, 2012). Participants stressed the need to prioritize health and wellness as an essential part of organizing, as no activist movement can function if its members are burnt out.

Participants also spoke of feeling politically re-energized to mobilize with other people during this time. Scholar and activist Kim Tran (2020) shared the hope that people "(re) commit to movement work ... and focus on building people power, building with each other" (@but_im_kim_tran, 10 April). The theme of interdependence in this Tweetchat draws heavily from Leah Lakshmi Piepzna-Samarasinha, whose writing on building care webs and mutual aid networks is also heavily featured within AAFC's zine. Drawing from the disability justice movement, Piepzna-Samarasinha (2018) intervenes on crash-and-burn emergency models of rapid response, often deployed in the midst of crisis, by highlighting the necessity for models of collective organizing that center "sustainability, slowness, and building for the long haul" (p. 53). Participants observed that in the wake of disaster, rather than formal institutions responding directly or quickly to community needs, local grassroots organizations led community recovery. These groups have few resources but hold deep knowledge of a specific neighborhood and build infrastructures and networks for aid and support (Hong, 2012).

\section{"A World Built for All of Us"-Connecting Pasts, Presents, Futures}

Community care over capital gain ... A world built for all of us and run by all of us. (Asian American Feminist Collective, 2020c, April 10)

Participants discussed how histories of racial violence have facilitated the creation of spaces where disabled, trans, and economically disadvantaged people were not prioritized. The third theme that we identified from the Tweetchat highlighted how participants relied on their historical knowledge to make sense of the current COVID-19 outbreak, using history to drive their analyses and articulate their political positioning. They drew on these histories to generate imaginations for future worlds and possibilities. For example, Lausan (2020), a Hong Kong magazine, described the trauma of the SARS outbreak in 2003 and how mutual care practices undertaken during coronavirus are in our collective "muscle memory" (@LausanHK, April 10). Alison Roh Park (2020), a poet and writer, shared that she woke up feeling "intergenerational aches in my bones" (@alisonrohpark, April 10). The description of bodily memory as a visceral response to this moment demonstrates the embodiment of geohistorical politics of knowledge (Yoneyama, 2016). As people detailed the increase in harassment in their communities, they traced these painful experiences to transnational histories of colonization. For example, Heena Sharma (2020b) reflects on histories of genocide between Asian communities that has led to present-day "Hindu nationalist rhetoric further endangering the lives of Muslims who are being used as a scapegoat for 
this pandemic" (Sharma, 2020b, April 10). Participants reconstructed trauma narratives that transcend generations as embedded in collective memory, and share creative strategies of remembering (Kwan, 2020).

For many participants, the fear-mongering racist language from the Trump administration "blam[ing] China for their own mishandling of the pandemic" and observations that "Asian Americans are bearing the brunt of xenophobic attacks"(@DrHStilley, Kelly, 2020, 10 April) extended a long history of xenophobic racism in the United States, marked by the passage of events such as the Page Act, the Chinese Exclusion Act of 1882, and the Japanese internment during the Second World War, where Asian bodies represented a threat to the purity of (White) Western society in the form of "Yellow Peril" (Lee, 2007; Shah, 2001). In these cases, the circulation of information about who is deemed undesirable and unassimilable, from the stereotyping of Chinese immigrants as more likely to carry disease to the racialized constructions of Asians as threats and terrorists, has furthered racist projects of exclusion through anti-immigration and carceral policies. Drawing on the longer history of how Asians have been racialized as scapegoats in times of crisis, participants underlined a commonality of experience while also attempting to problematize the "perpetual foreigner" trope that reinforces the superiority and nativism of Eurocentric whiteness (Cheryan and Monin, 2005).

The Wing Luke Museum (2020) described the present moment as "American cultural amnesia in action" (@winglukemuseum, April 10). Here, the museum counters liberal erasures of historical violence in the pursuit of limited freedoms. Participants interrogated the present by calling attention to past conditions of injustice, as well imagining future possibilities, or "freedoms yet to come" (Lowe, 2015). The Tweetchat offered what Betina Hsieh (2020) described as an "affinity space" that allowed participants to unpack histories of oppression that make the disparities in this moment "historically predictable and not an anomaly" (@ProfHsieh, 10 April). Hsieh also added that we can only build solidarities if we know our own histories, "the ways in which we've bought into white supremacy, benefited from privilege and known oppressions" (@ProfHsieh, 10 April). In this vein, Tweetchat participants use historical recovery as a means to hold institutions of power more accountable. As historian Salonee Bhaman (2020) tweeted, "We have to build a language of solidarity and find a way to hold power accountable to those who are most vulnerable"(@saloneee, 10 April).

\section{Discussion: Making Feminist Politics}

The \#FeministAntibodies Tweetchat offered a particular alignment of race in a technocultural space, namely a specific orientation to Asian American collective politics. As information environments, digital platforms offer a site of political performance for collectives and individual actors to articulate politics (Hall \& Grossberg, 1986) and draw connections across differences at a particular conjuncture. The ways specific organizations, campaigns, and individuals mediate Asian American politics through discursive uses of platforms across different epistemological standpoints (Brock, 2016) demonstrate a particular orientation to Asian America as a political home and identity as well as the making and remaking of identity through technologies.

Facilitating together-ness in the midst of the COVID-19 pandemic has also shifted how digital connections become materialized. Recounting coordinating efforts to "be together" online with other people at a given time reveals the work involved in building a shared political home in digital space. By highlighting the friendships and relationships embedded within social movements and across technologies, we can see that digitally networked communications are not moments of seemingly spontaneous eruption, but instead involve both coordination work and deeper relationship building over time.

An observation and corresponding question that continues to emerge is the following: our current society is broken-so what is the society we desire for the future? This present moment of crisis and instability reveals a lot about what possibilities the future can hold, or how systems and institutions can and must be transformed. During the pandemic, social movements that have often been deemed as impractical or impossible suddenly seem within reach: free Internet, decarceration, eviction moratoriums, rent freezes, and loan payment suspensions can be possible. Through the discussion of intersectionality and interdependence, participants offered a critique of power, identifying the multiple ways that systems of racism and capitalism harm people collectively and how we might work together to imagine new systems.

Furthermore, bringing different histories together under the \#FeministAntibodies hashtag discursively mobilizes solidarities across differences. For example, Asian communities are often excluded from dominant discourses on incarceration, preventing cross-community solidarity. Free Them All (2020), a decarceration campaign, pointed out, "all forms of incarceration harm all of us" (Free Them All for Public Health, 2020, April 10). Participants drew upon different histories of state violence as a means toward building future coalitions. The Tweetchat ended with a question prompting participants to imagine future worlds, where participants brought together their previous discussions of intersectionality, interdependence, and history. Many posts focused on community-based organizing as a strategy toward abolishing and transforming present institutions and systems.

With an economy of hearts and likes, activism on digital spaces can sometimes be a "humming positivity machine" (Ryan, 2016) through the discursive circulation of happy words about community. As an immersive information environment that encourages infinite scrolling, Twitter also functions as a medium of compression, transmitting ideas 
in 280 characters or less. However, looking beyond the content of the Tweets themselves to bring in both historical context as well as discussion of the labor and process that generated them emphasizes how digital objects function as a medium where questions of identity and inequality are worked out and how relationships are made and built through conceptualizing and circulating writing and ideas. The level of curation and moderation of the Tweetchat does not afford for broad representations of Asian America, but instead articulates a specific vision of what Asian American collective politics might be.

\section{Conclusion}

The Asian American Feminist Collective's zine and corresponding Tweetchat digitally circulate the intergenerational arguments, histories, languages, and ideas that have shaped Asian American movement building and Asian American studies across multiple decades. Initiated alongside the "ethnic studies" as part of social justice movements in the 1960s and 1970s, Asian American studies originated as an academic field of study in the midst of racial and political crisis (Suyemoto \& Liu, 2018). Yet, as a field and as a political concept, "Asian American" also faced critical problems, including the tension between homogenizing "Asian American" and navigating internal diversity. The contradictions surrounding Asian American collective politics in the larger digital information environment during the COVID19 pandemic indicate political and intellectual tensions around how we build collective politics in ways that continue to account for uneven differences. As a political orientation and political "home," Asian America is continuously in the midst of rebuilding - and now, rebuilding across digital platforms. The recursive pull of Asian American political identity in navigating differences in the process of narrating collective politics has been central to how "Asian America" continues to form and reform, including in our digital spaces.

As examples of cultural politics across platforms, the zine and Tweetchat demonstrate an orientation to Asian America that reflects upon and responds to sociocultural and political histories. The process of political expression and content circulation through the curation of particular interlocutors across different technological and discursive forms produced a specific vision of Asian American politics. The threads emerging from these conversations function as forms of alignment and "being in line with others" (Ahmed, 2006, p. 15). As highlighted by both contributors to the zine and participants in the Tweetchat, the COVID-19 pandemic has revealed both the ongoing precarities of everyday existence in our communities as well as exposing who is unevenly at risk when social safety nets fail. While this moment is unique, activists and community organizers emphasize that "we" have also been here before. As expressed in the manifold community resources that circulate online, people marginalized by state violence hold extensive experience and knowledge on how to survive despite precarity and scarcity. Furthermore, these forms of knowledge also envision ideas on how to radically change systems so they no longer continue to render particular communities and people disposable.

As scholars and media-makers using collaboration as a feminist method, we emphasize the necessity of communitybased research projects that interrogate ongoing inequalities at the intersection of race, technology, labor, and migration. Continuing to extend scholarly arguments on the relationship between media and politics, we see community forms of knowledge production as central to intellectual and political inquiry. This study focuses on organizing during March and April 2020; with the long-lasting duration of the pandemic, future studies can further investigate shifts in processes of community organizing during crisis. Significantly, with uprisings beginning at the end of May 2020 in the wake of continued police violence against Black people and ongoing structural anti-Black racism, further attention should be paid to relational theorizations of race, including in studies of technology and social movements. This particular study also focuses on a small network of Asian American feminist media practitioners. As a distinctly Asian American form of media production, this particular study does not include critical engagements with Asian migrant and diasporic communities. Given how immigrants are uniquely positioned as vulnerable during this time, with matters such as immigration status and visas becoming increasingly politicized, future research in this sphere should engage these communities. To further understand and study the digital information environment in which Asian and Asian American politics form during the ongoing pandemic, future research could also look to media practices across diasporic platforms and networks. For example, the Chinese social media app WeChat functions as an alternative site to further examine collective politics. Furthermore, the intersectionality of Asian America could also be seen through testimonials and other media practices by domestic workers and taxi drivers impacted by the gig economy, sharing economy, and ondemand service apps.

As revealed by yet-increasing cases, hospitalizations, and deaths across the United States, the COVID-19 pandemic will have long-lasting implications on our communities, and we are only beginning to see the devastating social and economic impacts of the crisis. If we are pedagogically committed to redressing unequal differences in service of future world-building, this requires building alongside grassroots communities on the frontlines in shaping the meaning of Asian America as a formation.

\section{Acknowledgements}

The authors would like to extend a thank you to the "Care in the Time of Coronavirus" zine co-editors, Salonee Bhaman (AAFC), Matilda Sabal (Bluestockings), and Tiffany Diane Tso (AAFC), as well as additional co-leaders of the Asian American Feminist Collective, Julie Ae Kim and Senti Sojwal. They appreciate the 
time and contributions of all participants in the \#FeministAntibodies Tweetchat. In addition, they would like to thank other members of the AAPI COVID-19 Project collaborative research group, including Catherine Nguyen, Christina Ong, Susanna Park, Kara Takasaki, $\mathrm{Mu} \mathrm{Wu}$, and Liwei Zhang, as well as Jason Beckfield for ongoing support of their research.

\section{Declaration of Conflicting Interests}

The author(s) declared no potential conflicts of interest with respect to the research, authorship, and/or publication of this article.

\section{Funding}

The author(s) received no financial support for the research, authorship, and/or publication of this article.

\section{ORCID iD}

Rachel Kuo (iD https://orcid.org/0000-0002-6918-8916

\section{References}

Ahmed, S. (2006). Queer phenomenology: Orientations, objects, others. Duke University Press.

Allied Media Projects. (2020). Media-based organizing. https:// www.alliedmedia.org/media-based-organizing

Asian American Feminist Collective. (2020a, April). \#FeministAntibodies Tweetchat: Care in the time of coronavirus. Wakelet. bit.ly/feministantibodies

Asian American Feminist Collective. (2020b, April 6). [@aafcollective]. Twitter. https://witter.com/aafcollective/status/1247173433231839234

Asian American Feminist Collective.(2020c, April 10). [@aafcollective]. Twitter.https://twitter.com/aafcollective/status/12486707 49793095681

Bailey, M. (2015). \#Transform(ing)DH writing and research: An autoethnography of digital humanities and feminist ethics. Digital Humanities Quarterly, 9(2), Article 1.

Bascara, V., \& Nakamura, L. (2014). Adaptation and its discontents: Asian American cultural politics across platforms. Amerasia Journal, 40(2), ix-xviii.

Bhaman, S. (2020, April 10). @saloneee. Twitter. https://twitter. com/saloneee/status/1248659432940228610

Bhaman, S., Kuo, R., Sabal, M., Shaw, V., \& Tso, T. D. (2020). Care in the time of coronavirus. In Asian American Feminist Collective (Ed.), Asian American feminist antibodies: Care in the time of coronavirus. https://digitalcommons.wcl.american. edu/wlpanalyses/9/

Bonilla, Y., \& Rosa, J. (2015). \#Ferguson: Digital protest hashtag ethnography and the racial politics of social media. American Ethnologist, 42(1), 4-17.

Brock, A. (2015). Deeper data: A response to Boyd and Crawford. Media, Culture, and Society, 37(7), 1084-1088.

Brock, A. (2016). Critical technocultural discourse analysis. New Media \& Society, 20(3), 1012-1030.

Chau, M. (2020a, March 19). A comic on resiliency. Wing Luke Museum Newsletter. https://bit.ly/2yYKbF6

Chau, M. (2020b, April 10). [@monyeeart]. Twitter. https://twitter. com/monyeeart/status/1248663472788762624
Cheryan, S., \& Monin, B. (2005). Where are you really from? Asian Americans and identity denial. Journal of Personality and Social Psychology, 89(5), 717-730.

Chun, W. H. K. (2016). Habitual new media. MIT Press.

Collins, P. H. (2015). Intersectionality's definitional dilemmas. Annual Review of Sociology, 41, 1-20.

Devakumar, D., Shannon, G., Bhopal, S. S., \& Abubakar, I. (2020). Racism and discrimination in COVID-19 responses. The Lancet, 395(10231), Article 1194.

Equality Labs. (2020, April 10). [@equalitylabs]. https://twitter. com/EqualityLabs/status/1248658596117831680

Federici, S. (2012). Revolution at point zero: Housework, reproduction, and feminist struggle. PM Press.

Free Them All for Public Health. (2020, April 10). [@freethemall2020]. Twitter. https://twitter.com/FreeThemAll2020/status/1248660261445271552

Gilmore, R. W. (2007). Golden gulag: Prisons, surplus, crisis, and opposition in globalizing California. University of California Press.

Green, V. (2011). Race on the line: Gender, labor, and technology in the Bell System, 1880-1980. Duke University Press.

Hall, S., \& Grossberg, L. (1986). On postmodernism and articulation: An interview with Stuart Hall. Journal of Communication, $10(45), 45-60$.

Hanif, S.B.K.(2020,April 10).[@ShahanafromBK].Twitter.https:// twitter.com/ShahanaFromBK/status/1248672500550164483

Hong, S. (2012, November 7). Left in the dark: Inside the buildings of Chinatown after Hurricane Sandy. Asian American Writers Workshop. https://aaww.org/left-in-the-dark/

hooks, b. (1989). Choosing the margin as a space of radical openness. Framework: The Journal of Cinema and Media, 36, 15-23.

hooks, b. (1990). Homeplace: A site of resistance. In b. hooks (Ed.), Yearning: Race, gender, and cultural politics (pp. 41-49). South End Press.

Hsieh, P. (2020, April 10). [@ProfHsieh]. Twitter. https://twitter. com/ProfHsieh/status/1248660271716950016

Ishizuka, K. (2016). Serve the people: Making Asian America in the long sixties. Verso Books.

Iyer, D. (2017). We too sing America: South Asian, Arab, Muslim, and Sikh immigrants shape our multiracial future. The New Press.

Jackson, S. J. M., Bailey, M., \& Foucault Welles, B. (2020). \#HashtagActivism: Networks of race and gender justice. MIT Press.

Joseph, M. (2002). Against the romance of community. University of Minnesota Press.

Kelly, H. S. (2020, April 10). [@DrHStilley]. Twitter. https://twitter.com/DrHStilley/status/1249732882878345221

Kim, D., \& Kim, E. (2014). The \#TwitterEthics Manifesto. Model View Culture. https://modelviewculture.com/pieces/the-twitterethics-manifesto

Korn, J. (2017). Expecting penises in Chatroulette: Race, gender, and sexuality in anonymous online spaces. Popular Communication, 15(2), 95-109.

Kuo, R. (2017). Reflections on \#solidarity: Intersectional movements in APIA communities. In L. K. Lopez \& V. Pham (Eds.), Routledge companion to Asian American media. Routledge. https://www.routledgehandbooks.com/ doi/10.4324/9781315727745.ch16 
Kuo, R. (2018). Visible solidarities: \#Asians4BlackLives and affective racial counterpublics. Studies of Transition States and Societies, 10(2), 40-54.

Kwan, Y. Y. (2020). Time-image episodes and the construction of transgenerational trauma narratives. Journal of Asian American Studies, 23(1), 29-59.

Lausan, H. K. (2020, April 10). [@lausanhk]. Twitter. https://witter.com/lausanhk/status/1248660820030087171

Lee, E. (2007). "The Yellow Peril" and Asian exclusion in the Americas. Pacific Historical Review, 76(4), 537-562.

Lopez, L. K. (2016). Asian American media activism: Fighting for cultural citizenship. New York University Press.

Lowe, L. (1996). Immigrant acts: On Asian American cultural politics. Duke University Press.

Lowe, L. (1998). Work, immigration, gender: New subjects of cultural politics: Social justice: crossing lines: Revisioning U.S. Race Relations, 25(3), 31-49.

Lowe, L. (2015). History hesitant. Social Text, 125, 85-107.

McIlwain, C. (2017). Racial formation, inequality and the political economy of web traffic. Information, Communication \& Society, 20(7), 1073-1089.

Nakamura, L. (2011). Economies of digital production in East Asia: iPhone girls and the transnational circuits of cool. Media Fields Journal, 2. http://mediafieldsjournal.org/economies-of-digital/

Nakamura, L., \& Chow-White, P. (Eds.). (2013). Race after the Internet. Routledge.

Nash, J. (2019). Black feminism reimagined: After intersectionality. Duke University Press.

Nguyen, M. T. (2015). Minor threats. Radical History Review, $122,11-24$.

Nickel, P. M., \& Eikenberry, A. M. (2007). Responding to "natural" disasters: The ethical implications of the voluntary state. Administrative Theory \& Praxis, 29(4), 534-545.

Noble, S. N. (2016). A future for intersectional black feminist technology studies. Scholar \& Feminist Online, 13(3), 1-8.

Nodutdol. (2020, April 10). [@nodutdol]. Twitter. https://twitter. com/nodutdol/status/1248659624779223041

Park, A. (2020, April 10). [@alisonrohpark]. Twitter. https://twitter.com/alisonrohpark/status/1248659331115102209

Peek, L. (2011). Behind the backlash: Muslim Americans after 9/11. Temple University Press.

Piepzna-Samarasinha, L. L. (2018). Care work: Dreaming disability justice. Arsenal Pulp Press.

Piepzna-Samarasinha, L. L. (2020, March 9). Half-assed disabled prepper tips for preparing for a coronavirus quarantine. Google Docs. bit.ly/preppertips

RedCanary Song.(2020,April 10).[@redcanarysong].Twitter.https:// twitter.com/RedCanarySong/status/1248663620902359041

Rodriguez, J. M. (2014). Sexual futures, queer gestures, and other Latina longings. New York University Press.

Ryan, E. G. (2016, December 21). Pantsuit nation is the worst: Why a book of uplifting Facebook posts won't heal America. Daily Beast. http://www.thedailybeast.com/articles/2016/12/21/ pantsuitnation-is-the-worst-why-a-book-of-uplifting-facebook-posts-won-t-heal-america.html

Sabal, M. (2020, April 10). [@fierce_invalids]. Twitter. https:// twitter.com/fierce_invalids/status/1248661850474061827

Shah, N. (2001). Contagious divides: Epidemics and race in San Francisco's Chinatown. University of California Press.
Sharma, H. (2020a, April 10). [@heenasharma]. Twitter. https://twitter.com/heenasharma_/status/1248668277129216001

Sharma, H. (2020b, April 10). [@heenasharma]. Twitter. https://twitter.com/heenasharma_/status/1248670419114131461

Sharma, S. (2013). Black Twitter? Racial hashtags, networks and contagion. New Formations, 78, 46-64.

Shaw, V. (2017). We are already living together. In D. Goh \& C.M. Wang (Eds.), Precarious belongings: Affect and nationalism in Asia (pp. 59-76). Rowman \& Littlefield.

Shaw, V. (2020). Strategies of ambivalence: Cultures of liberal Antifa in Japan. Radical History Review, 138, 145-170.

Smith, B. (1989). A press of our own kitchen table: Women of color press. Frontiers: A Journal of Women Studies, 10(3), 11-13.

Steele, C. K. (2017). Black bloggers and their varied publics: The everyday politics of black discourse online. Television and New Media, 19(2), 112-127.

Suyemoto, K. L., \& Liu, C. M. (2018). Asian American students in Asian American studies: Experiences of racism-related stress and relation to depressive and anxious symptoms. Journal of Asian American Studies, 21(2), 301-326.

Tang, E. (2011). A gulf unites us: The Vietnamese Americans of Black New Orleans East. American Quarterly, 63(1), 117-149.

Tran, K. (2020, April 10). [@but_im_kim_tran]. Twitter. https:// twitter.com/but_im_kim_tran/status/1248670628531425280

Vis, F. (2013). A critical reflection on Big Data: Considering APIs, researchers and tools as data makers. First Monday, 18(10). https://firstmonday.org/ojs/index.php/fm/article/view/4878

Wing Luke Museum. (2020, April 10).[@winglukemuseum]. Twitter. https://twitter.com/winglukemuseum/status/12486573 24043993088

Wong, A. (2020). \#Coronavirus and the disability community. Wakelet. https:/wakelet.com/wake/1633ef52-2ade-43a9-b118 $-50 \mathrm{~d} 19 \mathrm{f} 821 \mathrm{cb} 7$

Yoneyama, L. (2016). Cold War ruins: Transpacific critique of American justice and Japanese war crimes. Duke University Press.

\section{Author Biographies}

Rachel Kuo (PhD, New York University) is a Postdoctoral Research Fellow at the Center for Information, Technology, and Public Life at the University of North Carolina at Chapel Hill. Her research focuses on race, social movements, and digital technology.

Amy Zhang (MA, University of Texas at Austin) is a doctoral student in Sociology at the University of Texas at Austin. Her research interests include social relationships and health at the intersections of gender, race, and immigration status.

Vivian Shaw (PhD, University of Texas at Austin) is a College Fellow at the Department of Sociology at Harvard University. Her interests are in the areas of race, gender, and sexuality in relation to disasters, the environment and social movements.

Cynthia Wang (PhD, University of Southern California Annenberg) is an Assistant Professor of Communication Studies at California State University, Los Angeles. She is interested in the impact of digital media on social relations framed in perspectives of time and temporality. 